\title{
Harapan Orang Tua terhadap Peran Perawat pada Anak dengan Hospitalisasi (Studi Fenomenologi)
}

\author{
Yuliastati $^{1}$, Farial Nurhayati ${ }^{2}$, Bram Burmana Jaya $^{3}$ \\ Program Studi Keperawatan Bogor, Politeknik Kesehatan Kemenkes Bandung, Indonesia \\ Email: yuliastati@gmail.com
}

\begin{abstract}
Parents Expectations on the Role of Nurses in Children with Hospitalisation (Study of Phenomenology). Hospitalization for children and parents is a very traumatic and stressful experience. Changes in the role, lack of sleep, feelings of pain, immobilization, unable to control yourself, a strange environment and changing daily habits are situations that are often felt by children that can trigger stress. For parents, stress occurs because of anxiety and fear resulting from the seriousness of the disease, procedures performed, treatment, the impact on the future of the child, frustration due to lack of information on procedures and treatment and unfamiliar hospital rules. Parental stress can be further increased when the health team shows an attitude of lack of empathy for them, limited information about caring for their children because of communication that is not well established with the health team, especially nurses and the involvement of parents in caring for their children. This study aims to identify what parents expect from the role of nurses when they care for their children in the hospital in this study. There are 5 themes: 1. Parental satisfaction over the improvement of the patient's condition, 2. Parental anxiety when the child is treated, 3. Adequate support for child care facilities 4. Communication barriers between patient-family nurses and 5. More attention is needed for pediatric patients from a nurse. This study is expected to improve the role of nurses, especially child nurses in carrying out nursing care according to the needs of patients and families.
\end{abstract}

Keywords: Hospitalization, Parental expectations, Role of pediatric nurses

\begin{abstract}
Abstrak: Harapan Orang Tua terhadap Peran Perawat pada Anak dengan Hospitalisasi (Studi Fenomenologi). Hospitalisasi bagi anak dan orang tua merupakan suatu pengalaman yang sangat traumatik dan penuh stres. Perubahan peran, kurang tidur, perasaan nyeri, immobilisasi, tidak dapat mengontrol diri, lingkungan yang asing dan kebiasaan sehari-hari yang berubah merupakan situasi yang sering dirasakan oleh anak yang dapat memicu timbulnya stres. Bagi orang tua, stres terjadi karena kecemasan dan ketakutan akibat dari seriusnya penyakit, prosedur yang dilakukan, pengobatan, dampak terhadap masa depan anak, frustasi karena kurang informasi terhadap prosedur dan pengobatan serta tidak familiarnya peraturan rumah sakit. Stres orang tua dapat semakin bertambah ketika tim kesehatan menunjukkan sikap kurang empati terhadap mereka, terbatasnya informasi tentang perawatan anaknya karena komunikasi yang tidak terjalin baik dengan tim kesehatan terutama perawat serta kurang dilibatkannya orang tua dalam perawatan anaknya. Penelitian ini bertujuan untuk mengidentifikasi apa saja sebenarnya harapan orang tua terhadap peran perawat saat mereka merawat anaknya di rumah sakit pada penelitian ini didapatkan 5 tema yaitu: 1. Kepuasan orang tua atas perbaikan kondisi pasien, 2. Kecemasan orang tua saat anak dirawat, 3. Dukungan fasilitas ruang rawat anak yang memadai 4. Hambatan komunikasi antara perawat-keluarga pasien dan 5. Perhatian lebih dibutuhkan pasien anak dari seorang perawat. Penelitian ini diharapkan dapat meningkatkan peran perawat terutama perawat anak dalam menjalankan asuhan keperawatan sesuai dengan kebutuhan pasien dan keluarga.
\end{abstract}

Kata kunci: Hospitalisasi, Harapan orang tua, Peran perawat

\section{PENDAHULUAN}

Hospitalisasi merupakan suatu keadaan dimana karena alasan yang terencana atau darurat, mengharuskan anak untuk tinggal di rumah sakit, menjalani terapi dan perawatan sampai pemulangannya kembali kerumah.
Selama proses tersebut, anak dan orang tua akan mengalami berbagai peristiwa yang dapat menjadi pengalaman sangat traumatik dan penuh stres (Wong, 2000).

Wilson (2010), mengungkapkan bahwa reaksi anak terhadap hospitalisasi sangat bervariasi, diantaranya adalah anak merasa 
sendiri, takut, marah dan sedih. Mereka juga merasakan bosan karena lingkungan yang tidak seperti di rumah, merasa tidak aman dan menginginkan perlindungan. Penelitian lain yang dilakukan oleh Bsiri-Moghaddam (2011), mengungkapkan bahwa hospitalisasi dapat membawa perubahan negatif, tekanan mental dan spiritual pada anak serta orang tua, juga dapat membahayakan kesehatan mereka. Kekhawatiran tentang beratnya penyakit anak, lingkungan rumah sakit, hubungan dengan petugas rumah sakit, masalah pribadi dan masalah emosional adalah beberapa faktor yang dapat meningkatkan stres bagi orang tua.

Bagi anak, stres yang dirasakan terutama adalah karena berpisah dengan lingkungan sebelumnya baik dengan keluarga maupun lingkungan tempat ia bersosialisasi. Stres juga dirasakan karena adanya perubahan peran, kurang tidur, perasaan nyeri, immobilisasi, tidak dapat mengontrol diri, lingkungan yang asing dan kebiasaan sehari-hari yang berubah. Bagi orang tua, stres terjadi karena kecemasan dan ketakutan akibat dari seriusnya penyakit, prosedur yang dilakukan, pengobatan, dampak terhadap masa depan anak, frustasi karena kurang informasi terhadap prosedur dan pengobatan serta tidak familiernya peraturan rumah sakit.

Masalah lain yang dapat memicu stres dan menambah beban bagi orang tua berkaitan dengan hospitalisasi anak adalah kurangnya komunikasi dengan pemberi perawatan dalam hal ini adalah perawat. Latour, et al (2010), dalam penelitiannya tentang pengalaman orang tua yang anaknya dirawat di ruang Pediatric Intensive Care Unit (PICU) menyatakan bahwa komunikasi yang terjalin antara orang tua dan tim kesehatan terutama perawat merupakan faktor yang sangat berpengaruh terhadap stres yang timbul pada orang tua. Kurangnya informasi dari perawat tentang kondisi anaknya ditambah dengan kurangnya sikap emphaty perawat akan meningkatkan stres orang tua. Interaksi antara orang tua dan tim kesehatan menjadi faktor yang sangat penting dalam kelangsungan pemenuhan kebutuhan perawatan anak.

Orang tua membutuhkan dukungan dan akses yang tidak terbatas dengan perawat, mendapatkan informasi yang jujur dan lengkap, memberikan kepercayaan pada dokter untuk melakukan tindakan demi menyelamatkan nyawa anaknya dan kesamaan informasi antara tim kesehatan. Orangtua menghargai perawatan yang tidak menghakimi, empati, dan dukungan moral dari petugas kesehatan. Komunikasi yang baik dengan keluarga dan dilibatkannya orang tua dalam merawat anak (misalnya memandikan, memeluk anak) adalah hal yang dapat membantu orang tua menurunkan stresnya (Brooten, 2013).

Orang tua berharap perawat melibatkan mereka dalam perawatan anaknya dengan tetap memperhatikan aspek sosio kultural serta respon keluarga, menghargai bahwa kesedihan orang tua bisa dijadikan sebagai suatu kekuatan, dilibatkan dalam pengambilan keputusan, didengarkan keluhan dan diperhatikan kebutuhannya.Beban orang tua dapat dikurangi dengan memberikan informasi yang dibutuhkan, memberidukungan emosional, menyediakan lingkungan budaya, psikologis, dan fisik yang aman bagi keluarga, memberikan bimbingan antisipasi untuk memandu dalam merawat anaknya terutama selama fase akut dan memberikan bantuan untuk belajar dan menyesuaikan diri dengan situasi yang dialami Roscigno (2016).

Pengalaman hospitalisasi pada anak hakekatnya merupakan suatu usaha untuk kembali sehat dan secara keseluruhan anak mendapatkan kembali status dirinya. Perawat dapat mempermudah proses ini dengan menunjukkan pada anak dan orang tua tentang manfaat hospitalisasi salah satunya adalah mereka dapat menyesuaikan diri dengan lingkungan yang baru. Hal ini memungkinkan perawat dapat memanfaatkan metode untuk membantu adaptasi individu dengan cara menggali kekuatan yang ada dalam dirinya untuk mempercepat pemulihan anak. Hal penting lainnya yang perlu diperhatikan oleh perawat adalah aspek spiritual dan kepercayaan pada Tuhan. Kepercayaan orang tua pada Tuhan dapat memberikan ketenangan kepada mereka dalam melewati masa-masa sulitnya.Perawat dapat memberikan motivasi kepada orang tua untuk selalu mendekatkan diri kepada Tuhan terutama disaat-saat kritis dengan mendorong mereka terus berdoa untuk kesembuhan anaknya (BsiriMoghaddam, 2011).

Tujuan penelitian ini untuk menggali lebih dalam tentang harapan-harapan orang tua terhadap peran perawat dalam merawat anaknya yang sedang mengalami hospitalisasi di RS PMI Kota Bogor.

\section{METODE}

Jenis penelitian kualitatif dengan studi fenomenologi. Pengumpulan data menggunakan teknik wawancara mendalam (in depth interview). Hal ini dilakukan untuk mendapatkan informasi yang lebih dalam tentang harapan orang tua terhadap peran perawat terhadap anak 
yang menjalani hospitalisasi. Penelitian ini dilakukan di Ruang rawat anak RS PMI Bogor.

Informan pada penelitian ini adalah orang tua pasien anak yang dirawat di RS PMI Bogor. Jumlah partisipan pada penelitian ini sebanyak 10 orang. Cara mendapatkan informan tersebut peneliti meminta informasi dari perawat ruang anak sebagai informan kunci, Wawancara dilakukan di Ruang konsultasi RS PMI Bogor dan dilanjutkan di rumah pasien untuk klarifikasi data. Data diperoleh dari informan dengan menggunakan teknik wawancara mendalam. Data yang diperoleh dari informan diklarifikasi ke perawat ruang anak.

Manajemen data pada penelitian ini dilakukan secara manual dengan pembuatan transkrip verbatim. Data file dipisahkan berdasarkan tema-tema dengan menggunakan tabel analisis tema. Setelah melakukan wawancara, peneliti mendengarkan kembali hasil rekaman wawancara, setelah itu mengulang mendengarkan dan membuat transkrip hasil wawancara. Peneliti mencocokkan transkrip dengan hasil rekaman wawancara. Peneliti membaca hasil transkrip kembali sampai memahami data. Kemudian dilakukan reduksi data dengan membuat rangkuman yang merupakan hal pokok yang akan menjadi fokus penelitian yaitu mengenai harapan orang tua terhadap peran perawat selama anaknya di rawat di rumah sakit.

Penelitian ini telah mendapatkan Persetujuan Etik Penelitian Kesehatan (Ethical Clearance) (Nomor: 14/KEPK/PE/VI/2018) dari Komisi Etik Penelitian Kesehatan Politeknik Kesehatan Kementerian Kesehatan Bandung.

\section{HASIL}

Berdasarkan hasil wawancara didapatkan bahwa sebagian besar partisipan (7 orang) mengaku baru sekali ini mempunyai pengalaman anaknya di rawat di rumah sakit. Sisanya sebanyak 3 orang partisipan mengaku sudah lebih dari satu kali anaknya dirawat di rumah sakit.

Pada penelitian ini didapatkan 5 tema yaitu : 1. Kepuasan orang tua atas perbaikan kondisi pasien, 2. Kecemasan orang tua saat anak dirawat, 3. Dukungan fasilitas ruang rawat anak yang memadai 4. Hambatan komunikasi antara perawat-keluarga pasien dan 5. Perhatian lebih dibutuhkan pasien anak dari seorang perawat.
Tema 1. Kepuasan orang tua atas perbaikan kondisi anaknya.

Tema pertama yang diangkat pada penelitian ini adalah kepuasan orang tua atas perbaikan kondisi pasien selama dirawat di rumah sakit. Tema ini muncul berdasarkan beberapa kategorik yang menyatakan tentang perbaikan kondisi anak dan keluhan berkurang setelah anak mendapatkan perawatan. Seluruh partisipan mengatakan anaknya mengalami perbaikan kondisi selama dirawat di RS.

"Ada perubahan, sekarang sudah baikan.
gak mual lagi...(I1)
"Kondisi anak awalnya demam, sekarang
sudah lebih baik"...(I2)
"Sudah baikan, seger karena sudah
transfusi. tadinya ga enak makan, ga enak
tidur..."(13)

Tema 2: Kecemasan orang tua saat anak dirawat

Tema ini timbul dari kategorik-kategorik kegelisahan orang tua, berbagi peran dan Ingin mengetahui perkembangan anak di RS. Seluruh partisipan ingin menunggui anaknya yang sedang sakit di RS.

"Pengen sembuh, jangan sakit-sakit. Sering sakit, panas, takut kena flek, tapi ngga katanya mah... "(I5)

"Dirumah masih ada anak-anak, ada suami dirumah suami sudah biasa merantau, jadi sudah mandiri..(I6)

"Saya dan suami menunggu anak di RS, pegen anak cepet sembuh, cepet pulang..."(17)

Tema 3: Dukungan fasilitas sarana prasarana untuk perawatan pasien anak.

Dukungan fasilitas sarana prasarana untuk perawatan pasien anak merupakan tema ketigadalam penelitian ini. Tema ini timbul dari kategorik-kategorik fasilitas memadai dan peningkatan fasilitas.

"Fasilitas sudah sesuai, cukup bagus..hanya terganggu dengan pasien lain.." (P6)

"Kamar mandi sebaiknya di dalam, kalo diluar bolak-balik pintu harus ditutup, takut nularin..'(P7)

"Ditingkatkan lagi fasilitas ruang rawatnya, ada mainan anak dan toilet khusus anak..”(P8) 
Tema 4: Hambatan komunikasi antara perawatkeluarga pasien

Tema ini timbul dari kategorik-kategorik peraasaan takut komunikasi dan informasi dari perawat kurang. Ada empat orang partisipan ada rasa tidak enak untuk berkomunikasi dengan perawat.

"Namanya epilepsy serangannya pas lagi
tidur seranganya kalo anak saya seranganya
pas lagi tidur. Saya bingung karena apa,
karena kan lagi tidur,..."(P1).
"Perawat menjelaskan kondisi pasien anak.
Saya belum pernah nanya tentang
penyakit... Saya mau tanya takut dikira
bawel gitu.." (P4).
"Tindakan sesuai, cepat, tapi kurang
komunikasi, saat suntik, ga dijelasin obat
apa gitu, he.. he..."(P8).
"Saya mau tanya-tanya banyak tentang
anak saya takut, takut perawatnya marah
saya tanya terus...(P9).

Tema 5: Perhatian lebih dibutuhkan pasien anak dari seorang perawat.

Perhatian lebih dibutuhkan pasien anak dari seorang perawat adalah tema kelima dalam penelitian ini. Tema ini timbul dari kategorikkategorik peran perawat anak sesuai dan perawat lebih care lagi kepada pasien anak.

"Perawat baik-baik. Alhamdulillah kalo
dulu suka judes..gituu..Perawat cepat
melakukan tindakan,
mengecewakan.."(P1)
"Harus lebih baik lagi. Klo saya nanya,
dalam hal merawat anak saya. Sudah baik-
baik perawatnya. .(P4)
"Perawat ramah, kita juga enak. Mau Tanya
apa aja enak.."(P2).
"Suka anak dihibur kalo nangis. Suntik dulu
ya ade..sekarang anak udah jarang nangis,
waktuawal liat suster nangis.."(P5).
"Perawat lebih baik lagi, kasih penjelasan
yang lebih jelas, tidak nunggu
ditanya.."(P8).

\section{PEMBAHASAN}

Berdasarkan hasil penelitian didapatkan lima tema tentang harapan orang tua terhadap perawat ketika anaknya dirawat di rumah sakit. Tema-tema tersebut didapatkan setelah dikategorisasi berdasarkan pernyataanpernyataan yang dikemukakan oleh orang tua.

Asuhan keperawatan yang dilakukan oleh perawat pada dasarnya adalah ditujukan untuk kepuasan pasien dan keluarga karena kepuasan pasien dan keluarga merupakan hal dasar yang harus diperhatikan oleh petugas kesehatan khususnya perawat dalam merawat pasien selama di rumah sakit. Kepuasan pasien merupakan indikator kualitas pelayanan kesehatan yang diberikan.

Beberapa keluhan terkait kepuasan pasien terhadap pelayanan yang didapatkan biasanya terkait dengan respon perawat dalam menanggapi keluhan yang berdampak pada ketidakpuasan pasien dan keluarga. Lambatnya respon perawat dalam menanggapi keluhan pasien dan keluarga sehingga keluhan harus disampaikan berkali-kali, perawat kurang empati terhadap keluhan pasien dan keluarga serta fasilitas perawatan yang tidak memadai adalah beberapa hal yang menjadi keluhan pasien dan keluarga yang dapat berdampak pada menurunnya kualitas pelayanan. Salmani, et al (2015) mengungkapkan bahwa kepuasan merupakan proses perilaku yang melibatkan aspek kognitif-emosional. Semua komponen pelayanan seperti perawat, dokter, tim kesehatan yang lain, seluruh staf bahkan direktur harus terlibat dan berkomitmen dalam meningkatkan kepuasan pasien dan keluarga. Asuhan keperawatan anak dalam konteks keluarga dan penerapan traumatik care merupakan prioritas yang harus diterapkan oleh perawat selama anak dirawat di rumah sakit. Manajemen perawatan senantiasa ditujukan untuk kepuasan pasien dan keluargadan disusun secara matang mulai dari perencanaan sampai dengan evaluasi serta diawasi pelaksanaannya. Hal ini dilakukan semata-mata untuk kualitas asuhan keperawatan dan mencapai kepuasan yang lebih besar pada orang tuadan keluarga.

Bagi orang tua, proses hospitalisasi pada anak dapat merupakan pengalaman yang tidak mengenakan karena hospitalisasi dapat membawa perubahan negatif, tekanan mental dan spiritual juga dapat membahayakan kesehatan mereka. Kekhawatiran tentang beratnya penyakit anak, lingkungan rumah sakit, hubungan dengan petugas rumah sakit, masalah pribadi dan masalah emosional adalah beberapa faktor yang dapat meningkatkan stres dan kecemasan pada orang tua. Seringnya orang tua bertanya kepada perawat tentang kondisi kesehatan anaknya merupakan salah satu indikator bahwa mereka cemas dan meminta kepastian tentang kondisi kesehatan anak yang sebenarnya. 
Perawat dapat melakukan intervensi untuk menurunkan stres dan perasaan cemas orang tua dengan memfasilitasi orang tua memenuhi kebutuhannya. Orang tua membutuhkan dukungan dan akses yang tidak terbatas dengan perawat, mendapatkan informasi yang jujur dan lengkap, memberikan kepercayaan pada dokter untuk melakukan tindakan demi menyelamatkan nyawa anaknya dan kesamaan informasi antara tim kesehatan. Orangtua menghargai perawatan yang tidak menghakimi, empati, dan dukungan moral dari perawat. Komunikasi yang baik dengan keluarga dan dilibatkannya orang tua dalam merawat anak (misalnya memandikan, memeluk anak) adalah hal yang dapat membantu orang tua menurunkan stresnya (Brooten, 2013).

Beberapa hal bisa dilakukan oleh perawat untuk membantu anak dan orang tua mengurangi kecemasan akibat hospitalisasi dengan meminimalkan dampak perpisahan dengan senantiasa menghadirkan dan melibatkan orang tua dalam setiap aktivitas perawatan anak sekaligus juga bertujuan untuk mencegah perasaan kehilangan anak. Memaksimalkan manfaat dari hospitalisasi dengan membantu memfasilitasi perubahan ke arah positif antara anak dan anggota keluarga dengan cara membantu perkembangan hubungan orang tuaanak, memberi kesempatan pada orang tua untuk belajar tentang pertumbuhan dan perkembangan anak sehingga orang tua dapat berespons positif apabila ada perubahan pada anak seperti regresi dan agresif. Memberi Informasi sehubungan dengan penyakit, pengobatan, serta prognosa, reaksi emosional anak terhadap sakit dan dirawat, serta reaksi emosional anggota keluarga terhadap anak yang sakit dan dirawat (Wong, 2007).

Hal tersebut juga dikuatkan oleh Makworo, et al., (2016) yang menyatakan bahwa pelibatan orang tua dalam perawatan anak diyakini dapat menurunkan tingkat kecemasan mereka. Keterlibatan orang tua dalam perawatan anak dapat dilakukan melalui beberapa kegiatan seperti orang tua didorong untuk mendampingi saat proses pemeriksaan dan tindakan perawatan. Banyak rumah sakit yang telah menerapkan kebijakan ini. Keterlibatan orang tua saat perawatan membantu perawat memudahkan dalam melakukan pengkajian dan saat melaksanakan tindakan. Orang tua didorong untuk bersama anak di setiap saat. Menghadirkan orang tua untuk melakukan atau membantu dalam pelaksanaan beberapa prosedur juga dapat mengurangi kecemasan dan katakutan anak .

Walaupun keterlibatan orang tua penting dalam proses perawatan, tetapi ada beberapa orangtua yang takut menemani anak saat dilakukan prosedur tertentu walaupun perawat membutuhkan bantuan orang tua seperti untuk menenangkan anak. Orang tua merasa tidak tega dan memilih untuk menjauh meninggalkan anak sendirian dengan perawat. Beberapa prosedur invasif seperti lumbal fungsi, resusitasi membuat orang tua tidak tega melihat anaknya dan membuat mereka trauma sehingga lebih memilih untuk tidak mendampingi anaknya (Makworo, et al., 2016).

Kecemasan akan kondisi penyakit anak dapat dikurangi dengan cara memberikan informasi yang jelas tentang kondisi dan proses perawatan pada anak serta memberikan keleluasaan pada orang tua untuk mendampingi anak selama perawatan di rumah sakit. Intervensi ini juga dapat meningkatkan ikatan diantara anak dan orang tua (Makworo, et al., 2016).

Pada akhirnya pengalaman hospitalisasi merupakan suatu usaha untuk kembali sehat dan secara keseluruhan anak mendapatkan kembali status dirinya. Perawat dapat meminimalkan trauma dengan menunjukkan pada anak dan orang tua tentang manfaat hospitalisasi salah satunya adalah mereka dapat menyesuaikan diri dengan lingkungan yang baru. Hal penting lainnya yang perlu diperhatikan oleh perawat adalah aspek spiritual dan kepercayaan pada Tuhan. Kepercayaan orang tua pada Tuhan dapat memberikan ketenangan kepada mereka dalam melewati masa-masa sulitnya. Perawat dapat memberikan motivasi kepada orang tua untuk selalu mendekatkan diri kepada Tuhan terutama disaat-saat kritis dengan mendorong mereka terus berdoa untuk kesembuhan anaknya (BsiriMoghaddam, 2011).

Bagaimanapun, hospitalisasi merupakan peristiwa yang dapat menimbulkan pengalaman traumatik dan penuh stres tidak hanya bagi anak tetapi juga bagi orang tua (Wong, 2000). Bagi anak, stres yang dirasakan terutama adalah karena berpisah dengan lingkungan sebelumnya baik dengan keluarga maupun lingkungan tempat ia bersosialisasi. Stres juga dirasakan karena adanya perubahan peran, kurang tidur, perasaan nyeri, immobilisasi, tidak dapat mengontrol diri, lingkungan yang asing dan kebiasaan sehari-hari yang berubah. Bagi orang tua, stres terjadi karena kecemasan dan ketakutan akibat dari seriusnya penyakit, prosedur yang dilakukan, pengobatan, dampak terhadap masa depan anak, frustasi karena kurang informasi terhadap prosedur dan pengobatan serta tidak familiernya peraturan rumah sakit.

Atraumatic care atau perawatan atraumatik sebagai suatu strategi perawatan pada anak diyakini dapat mengurangi dan menurunkan 
tingkat stres pada anak akibat hospitalisasi. Perawatan atraumatik sendiri menurut Wong didefinisikan sebagai perawatan yang meminimalkan stres psikologis dan fisik pada anak yang diakibatkan oleh penyakit. Kehadiran orang tua setiap saat dapat membantu mengurangi kecemasan anak-anak. Selain itu keterlibatan orang tua dalam perawatan anak juga dapat menurunkan tingkat stres anak dan orang tua. Strategi lain yang dapat digunakan untuk mengurangi stres saat hospitalisasi adalah memodifikasi lingkungan tempat anak di rawat. Menghadirkan suasana ruang perawatan seperti di rumah dengan mendekorasi dinding menggunakan poster atau kartu bergambar sehingga anak-anak merasa nyaman, membawa barang-barang favorit dari rumah ke rumah sakit seperti selimut, boneka, botol, alat makan, atau pakaian dapat meningkatkan adaptasi dan dapat memberikan rasa nyaman dan ketenangan bagi anak.

Keberhasilan perawatan pada anak salah satunya dipengaruhi oleh adaptasi mereka terhadap lingkungan rumah sakit dimana anak di rawat. Mendekatkan suasana ruang perawatan seperti di lingkungan rumah dan tetap memperhatikan kebutuhan anak untuk tumbuh dan berkembang sesuai usianya adalah syarat mutlak yang harus difasilitasi oleh rumah sakit untuk meningkatkan kepuasan pasien dan orang tua.

Hal ini sejalan dengan penelitian yang dilakukan oleh Bsiri-Mogaddam et al (2011), yang mengungkapkan bahwa orang tua dengan anak yang mengalami hospitalisasi merasa tidak puas tentang lingkungan rumah sakit seperti suasana bising, keadaan tempat tidur yang tidak memenuhi syarat, pakaian, peralatan, kondisi makanan rumah sakit, aturan rumah sakit dan jam kunjungan yang dibatasi. Keadaan ini menambah stres mereka selama menjalani proses hospitalisasi.

Berdasarkan hal tersebut maka Royal Australasian College of Physicians. Paediatrics and Child Health Division (2008), menjelaskan ruang anak yang sesuai standar harus memenuhi syarat sebagai berikut:

a. Ruangan anak diatur sedemikian rupa dengan tempat tidur yang aman dan nyaman bagi anak serta tetap memperhatikan pedoman untuk pencegahan infeksi nosokomial. Sediakan juga fasilitas untuk orang tua saat mereka menunggui anaknya.

b. Mudah diamati dan diawasi setiap saat oleh perawat.

c. Terdapat ruangan khusus untuk melakukan prosedur d. Tersedia ruang isolasi untuk anak-anak dengan penyakit menular

e. Akses mudah ke fasilitas toilet dan kamar mandi yang khusus ditujukan untuk anakanak. Jika tidak mungkin memiliki fasilitas toilet atau kamar mandi terpisah, orang tua atau perawat harus menemani anak saat mereka ke kamar mandi.

f. Terdapat fasilitas bermain atau ruang bermain baik di dalam maupun di luar ruang perawatan.

g. Dekorasi ruangan dirancang sesuai dengan usia, termasuk peralatan dan instrumen yang digunakan. Pencahayaan ruangan juga hendaknya diperhatikan sehingga anak tidak takut.

h. Batasi tindakan fisik yang dapat menimbulkan trauma pada anak, perhatikan keamanan dan keselamatan anak saat melakukan tindakan.

i. Perhatikan aspek psikososial pada anak.

Ruang rawat anak sebagai fasilitas penunjang pelayanan keperawatan dengan desain yang menarik dan dilengkapi sarana sesuai dengan tingkat perkembangan anak dapat meningkatkan kenyamanan anak. Anak dengan hospitalisasi membutuhkan kenyamanan yang baik karena hospitalisasi dapat menjadi pengalaman traumatik bagi anak terutama anak usia muda. Ruang isolasi diperlukan untuk. kasus anak dengan penyakit menular atau anak dengan daya imun yang rendah. Menurut beberapa partisipan fasilitas untuk ruang perawatan anak sudah sesuai dengan kebutuhan perawatan yang sesuai dengan penyakit anak, namun perlu ditingkatkan lagi untuk fasilitas yang terkait khusus perkembangan pada anak seperti perlu disediakan toilet untuk anak, sarana untuk bermain anak. Selama anak sakit perekembangan anak harus diperhatikan khusus nya perkembangan psikososial anak seperti berinteraksi dengan teman sebaya, beramin sesuai dengan perkembangan usia dan kebutuhan belajar.

Komunikasi yang berkualitas tinggi antara perawat dan keluarga pasien merupakan kunci dari seni dan ilmu keperawatan karena hal ini memiliki dampak yang signifikan terhadap kesejahteraan pasien serta kualitas dan hasil perawatan dan secara keseluruhan berdampak pada kepuasan keluarga pasien itu sendiri. Beberapa faktor yang dapat menghambat berlangsungnya komunikasi yang baik antara perawat dan keluarga diantaranya adalah jumlah perawat yang tidak memadai, terlalu banyak dokumentasi keperawatan yang harus dibuat, waktu tunggu terlalu lama dan kurangnya 
perawat spesialis. Inilah sebabnya mengapa komunikasi yang baik antara perawat dan keluarga menjadi tergantung dari keduanya (Loghmani, et al., 2014).

Bagi perawat, komunikasi dengan pasien dan keluarga merupakan suatu keterampilan yang harus selalu diasah karena komunikasi merupakan bagian penting dari pekerjaan perawat sehari-hari. Kekhawatiran tentang kondisi dan beratnya penyakit anak mendorong orang tua untuk selalu ingin bertanya kepada perawat karena mereka yakin perawat mengetahui kondisi yang sebenarnya dari anak mereka.

Pertanyaan yang berulang-ulang dari orang tua atau anggota keluarga lainnya kadang-kadang membuat perawat merasa tidak nyaman sehingga memicu respon yang negatif dari perawat terhadap orang tua. Keadaan seperti ini dapat menimbulkan konflik antara perawat dengan orang tua sehingga dapat menambah beban dan stres orang tua. Situasi seperti ini sejalan dengan penelitian yang dilakukan oleh Latour, et al (2010), dalam penelitiannya tentang pengalaman orang tua yang anaknya dirawat di ruang Pediatric Intensive Care Unit (PICU) menyatakan bahwa komunikasi yang terjalin antara orang tua dan tim kesehatan terutama perawat merupakan faktor yang sangat berpengaruh terhadap stres yang timbul pada orang tua. Kurangnya informasi dari perawat tentang kondisi anaknya ditambah dengan kurangnya sikap empati perawat akan meningkatkan stres orang tua. Interaksi antara orang tua dan tim kesehatan menjadi faktor yang sangat penting dalam kelangsungan pemenuhan kebutuhan perawatan anak.

Banyaknya tugas yang harus dikerjakan oleh perawat dalam merawat pasien dapat membuat perawat menjadi kurang empati kepada pasien terutama orang tua. Mereka mungkin memiliki pertanyaan, kekhawatiran, atau informasi yang perlu disampaikan kepada perawat sehingga tidak ada salahnya perawat perlu mengambil waktu ekstra untuk secara khusus mendengarkan keluhan orang tua tentang perawatan anaknya.

Dalam penelitian lain, Loghmani, et al (2014) mengemukakan beberapa cara yang dapat dilakukan oleh perawat untuk memfasilitasi lancarnya komunikasi dan menghilangkan hambatan komunikasi yaitu dengan cara:

a. Memfasilitasi faktor-faktor yang

berhubungan dengan komunikasi antara perawat dan keluarga dengan memperhatikan beberapa hal yaitu:

- Memperhatikan aspek spiritual: berikan harapan, selalu mengingatkan akan keberadaan Tuhan dan memfasilitasi untuk pelaksanaan ibadah.

- Memberikan dukungan emosional: berikan dukungan mental, empati, saling pengertian, berikan kenyamanan dan bina saling percaya

- Partisipasi: libatkan keluarga dalam mengambil keputusan dan perawatan pasien

- Pemberian informasi: identifikasi informasi yang dibutuhkan oleh keluarga, tanggapi informasi yang dibutuhkan keluarga, berikan pendidikan kesehatan kepada keluarga untuk meningkatkan pengetahuannya

- Konsultasi: konsultasi dengan keluarga tentang terapi yang terbaik untuk pasien, konsultasi untuk perawatan yang terbaik khususnya jika pasien sudah pulang ke rumah dan masih membutuhkan perawatan lanjutan.

b. Hambatan komunikasi antara perawat dan orang tua/keluarga

- Salah pengertian tentang perawatan yang dibutuhkan: perbedaan keyakinan tentang kesehatan antara perawat dan keluarga, persepsi keluarga tentang perlakuan yang tidak adil dari perawat, konflik dengan anggota keluarga pasien, miskomunikasi, perawat memaksa pasien dan keluarga untuk mematuhi perintahnya, masalahmasalah yang berhubungan dengan sumber daya manusia.

- Masalah-masalah yang berhubungan dengan tugas dan pekerjaan: masalah profesionalitas perawat, masalah dengan perawatnya itu sendiri, perawat tidak mngindahkan kode etik dan masalah dengan lingkungan pekerjaan.

- Kesulitan-kesulitan yang berhubungan dengan pasien: masalah dengan persyaratan dan proses pembayaran serta masalah-masalah yang berhubungan dengan pasien.

Komunikasi terapeutik yang dilakukan oleh perawat kepada keluarga pasien anak dan keluarganya harus dilakukan secara efektif. Hambatan yang sering terjadi pada waktu komunikasi perawat dengan pasien anak adalah perawat tidak memahami komunikasi anak terutama untuk anak usia balita yang masih belum jelas pengucapan katanya. Perawat harus dapat berkomunikasi dengan pasein anak sevara efektif, untuk hal ini perawat memerlukan orang tua atau keluarga yang mengerti bahasa anak sehingga tidak menimbulkan mispersepsi antara 
perawat dengan pasien dan keluarga. Banyak pasien anak juga tidak mau berkomunikasi dengan perawat yang dalam hal ini dipandang sebagai orang asing bagi anak. Perawat dapat menggunakan cara atau strategi dalam pendekatan kepada anak seperti dengan cara bermain. Perawat bisa bermain cerita dengan pasien anak untuk menggali pengkajian kepada anak.

Anak bukan miniatur orang dewasa sehingga dalam penanganannya diperlukan pendekatan secara khusus yang berbeda dengan orang dewasa. Dalam keadaan sakit dan dirawat di rumah sakit, respon anak terhadap perawatan sangat berbeda dan bervariasi tergantung dari tingkat usia dan tahap perkembangannya.

Respon anak terhadap hospitalisasi secara umum dibagi menjadi 3 tahap yaitu

a. Tahap protes

Pada tahap ini anak biasanya bereaksi agresif terhadap perpisahan dengan orang tua dengan cara menangis keras, berteriak, mencari orang tua dengan isyarat matanya, memeluk erat orang tua, menghindari dan menolak kontak dgn orang yang tidak dikenalnya dan tidak dapat dihibur.

b. Tahap putus asa (Despair)

Anak biasanya menjadi tidak aktif, berhenti menangis, diam, kurang berminat terhadap makanan dan minuman, kurang berminat pada bermain dan tidak komunikatif. c. Tahap denial/menolak

Anak dapat menyesuaikan diri dengan kehilangan, anak menjadi lebih tertarik dengan lingkungan, bermain dengan orang lain, mulai melepaskan diri dengan orang tua dalam upaya menghindari rasa sakit dan mengatasinya dengan menciptakan persahabatan dengan orang lain.

Berbagai respon yang diperlihatkan anak menuntut perawat untuk lebih memperhatikan anak dengan bersikap lebih empati. Empati merupakan kemampuan untuk memahami dan menerima realita seseorang, merasakan perasaan dengan tepat, dan mengkomunikasikan pengertian kepada pihak lain. Teknik ini mengharuskan perawat untuk sensitif dan imajinatif, terutama jika perawat tidak memiliki pengalaman terdahulu dengan pasien. Empati merupakan kunci untuk menyelesaikan masalah dan mendukung komunikasi. Pernyataan empati bersifat netral, tidak menuduh, dan membantu pembentukan kepercayaan dalam situasi yang sulit (Potter \& Perry, 2009).

\section{SIMPULAN}

Pada penelitian ini didapatkan 5 tema yaitu: 1. Kepuasan orang tua atas perbaikan kondisi pasien, 2. Kecemasan orang tua saat anak dirawat, 3. Dukungan fasilitas ruang rawat anak yang memadai 4. Hambatan komunikasi antara perawat-keluarga pasien dan 5. Perhatian lebih dibutuhkan pasien anak dari seorang perawat.

\section{DAFTAR PUSTAKA}

Brooten, D, Youngblut, JM, Seagrave, L, Caicedo, C, Hawthorne, D, Hidalgo, I, Roche, R. (2013). Parent's Perceptions of Health Care Providers Actions Around Child ICU Death: What Helped, What Did Not. Am J Hosp Palliat Care. 30(1): 4049. Published online 2012 Apr 24. doi: 10.1177/1049909112444301.

Bsiri-Moghaddam, K, Basiri-Moghaddam,M, Sadeghmoghaddam, L, \& Ahmadi, F. (2011). The Concept of Hospitalization of Children from the View Point of Parents and Children. Iran Journal Pediatric, 21(2): 201-208. https://www.ncbi.nlm.nih.gov/pmc/articles /PMC3446164/.

Latour, JM, Van Goudoever, JB, Schuurman, BE, Albers, MJIJ, Van Dam, NAM, Dullaart, E, Van Heerde, M, Verlaat, CWM, Van
Vught, EM \& Hazelzet, JA. (2011). A qualitative study exploring the experiences of parents of children admitted to seven Dutch pediatric intensive care units. Intensive Care Med, 37:319-325, DOI 10.1007/s00134-010-2074-3.

Loghmani L, Borhani F, Abbaszadeh A. (2014). Factors Affecting the Nurse-Patients' Family Communication in Intensive Care Unit of Kerman: a Qualitative Study. Journal of Caring Sciences, 3(1): 67-82. Published online $2014 \quad$ Feb 27. doi: [10.5681/jcs.2014.008].

Makworo, D., Bwibo, N., \& Omoni, G. (2016). Implementation of family centered care in child health nursing: kenya paediatric nurses' experiences. Nurse Care Open. Acces Journal, 1(3), 15-17. 
Potter, P. A., \& Perry, A. G. (2010). Buku Ajar Fundamental Keperawatan Edisi 7. Jakarta: Salemba Medika.

Roscigno, .CI (2016). Parent Perceptions of How Nurse Encounters Can Provide Caring Support for the Family in Early Acute Care Following Children's Severe Traumatic Brain Injury. Journal of Neuroscience Nursing. $\quad 48(2)$ :E2-E15, DOI: 10.1097/JNN.0000000000000192.

Royal Australasian College of Physicians. Paediatrics and Child Health Division. (2008). Standards for the Care of Children and Adolescents in Health Services. Paediatrics \& Child Health Division, RACP.
Salmani N, Abbaszadeh A, Rasouli M, Hasanvand S. (2015). The Process of Satisfaction with Nursing Care in Parents of Hospitalized Children: A Grounded Theory Study, International Journal of Pediatric, Vol.3, N.6-1, Serial No.23, Nov 2015.

Wilson, M. E., Megel, M. E., Enenbach, L., \& Carlson, K. L. (2010). The voices of children: stories about hospitalization. Journal of Pediatric Health Care, 24(2), 95-102.

Wong, W. (2000). Buku Ajar Keperawatan Pediatrik, edisi 2. Jakarta: EGC. 